\title{
academicJournals
}

Vol. 8(1), pp. 52-57, 3 January, 2014

DOI: 10.5897/JMPR2013.5312

ISSN 1996-0875 (02014 Academic Journals

Journal of Medicinal Plants Research

http://www.academicjournals.org/JMPR

\section{Antidiabetic and genotoxic effects on Wistar rats treated with aqueous extract from Chrysobalanus icaco L.}

\author{
S. C. Ferreira-Machado ${ }^{1,2}$, R. F. Gagliardi ${ }^{3}$, A. P. M. Nunes ${ }^{2}$, M. P. Rodrigues ${ }^{2}$, F. J. S. Dantas ${ }^{2}$, \\ J. C. P. De Mattos ${ }^{2}$, C. A. F. Peregrino ${ }^{4}$, E. G. Moura ${ }^{5}$ and A. Caldeira-de-Araujo ${ }^{2 *}$ \\ ${ }^{1}$ Departamento de Biologia Geral, Universidade Federal Fluminense, Niterói, RJ, Brasil. \\ ${ }^{2}$ Departamento de Biofísica e Biometria, Instituto de Biologia Roberto Alcantara Gomes, Universidade do Estado do Rio \\ de Janeiro, Rio de Janeiro, Brasil. \\ ${ }^{3}$ Núcleo de Biotecnologia Vegetal, Instituto de Biologia Roberto Alcantara Gomes, Universidade do Estado do Rio de \\ Janeiro, Rio de Janeiro, Brasil. \\ ${ }^{4}$ Laboratório Universitário Rodolpho Albino, Universidade Federal Fluminense, Niterói, RJ, Brasil. \\ ${ }^{5}$ Departamento de Ciências Fisiológicas, Instituto de Biologia Roberto Alcantara Gomes, Universidade do Estado do Rio \\ de Janeiro, Rio de Janeiro, Brasil.
}

Accepted 1 December, 2013

Chrysobalanus icaco $\mathrm{L}$. is a medicinal plant, used to treat diabetes and dyslipidemia in Brazil. The biological effects may vary depending on the source of plant. Experiments were performed to assess these effects from plants collected in the field and those obtained from dried herbs market. Glycemia, cholesterol and triglycerides serum concentrations were measured in healthy and diabetic rats treated with aqueous extract of leaves. Diabetic rats treated with the extract showed lower serum triglycerides, but there was no significant difference $(P>0.05)$ in glycemia and cholesterol levels, compared to the control group without diabetes. Also, the genotoxic effects of these extracts were evaluated using the comet assay in total blood cells obtained from healthy rats ingested with extracts instead of drinking water. This assay showed that the extracts from either free market or endemic area were genotoxic. However, the extract obtained from the popular market was more genotoxic than that prepared from field plants. This study demonstrates that though the extract has therapeutic property that lowers the rate of triglycerides, it is not free of deleterious effects; this calls for precaution in its use as a phytotherapeutical agent.

Key words: Chrysobalanus icaco, cholesterol, comet assay, genotoxic potentiality, triglycerides, diabetes.

\section{INTRODUCTION}

The use of plants for therapeutic purposes is probably as old as human civilization (Akinboro and Bakare, 2007). The herbs used in alternative therapy have been intensively marketed in Brazil; they are found in free markets, pharmacies, supermarkets and specialty stores. When tagged, plant materials are called "natural products"; 
they have greater efficacy and fewer collateral effects compared to phytochemicals produced industrially (Gadano et al., 2006). Many of therapeutic activities attributed to certain plant drugs have no scientific support (Costa et al., 2008) and often times its ethnobotanic knowledge that directs phytochemical research of different metabolites and their biological effects.

Chrysobalanus icaco L. (Chrysobalanaceae) is a medium sized shrub known as abajeru, in Rio de Janeiro (Brazil). This species occurs in coastal areas of the American continent (Dahlgren, 1980; Ferreira-Machado et al., 2004) and is used as diuretic and hypoglycemic agent in the treatment of diabetes (Costa, 1977; VargasSimon et al., 1997; De Paulo et al., 2000). In folk medicine, this species is used in the form of tea prepared from various parts of the plant, especially leaves. In Northern Brazil, root is also used for this purpose (Coelho-Ferreira, 2009). There are pharmacological studies that show the antihyperglycemic property of some species of Chrysobalanaceae, as C. icaco (Presta and Pereira, 1987) and Parinari excelsa (Ndiaye et al., 2008), proving the effects reported in folk medicine. Phytochemical studies have evidenced the presence of myricetin-3-Oglucuronide, quercetin, and rutin, as well as other minor myricetin and quercetin derivatives in the hydroalcoholic extract of $C$. icaco leaves. It was shown that myricetin has both a hypoglycaemic and hypotriglyceridemic effect in diabetic rats (Ong and Khoo, 2000) and could thus have therapeutic value in the treatment of diabetes. These data could explain the traditional use of this species.

However, despite its popular use and beneficial biological effects, some cytotoxic effects have been found in this species. This way, in vitro experiments with aqueous extract revealed a potential genotoxic effect, as demonstrated either by induction of single strand breaks in plasmid DNA or by transformation efficiency reduction in bacteria (Ferreira-Machado et al., 2004). On this basis, it is also important to determine the biological effects by in vivo bioassays. In this context, the alkaline version of Single Cell Gel Electrophoresis (SCGE) or Comet Assay has been used by many investigators to evaluate the genotoxicity of several chemicals in vitro and/or in vivo (Tice et al., 2000; Santos et al., 2008; Costa et al., 2008; Verschaeve and Van Staden, 2008; Moretti et al., 2013). The unique design of the comet assay provides direct determination of the single and double-strand DNA breaks, alkali-labile lesions and indirect excisions caused by repair enzymes in individual cells (Rojas et al., 1999; Kim et al., 2002; Collins et al., 2008; Trzeciak et al., 2008).

In the present work, the effects of the aqueous extract of $C$. icaco from the endemic area of Rio de Janeiro, Brazil, were evaluated in rodents. Glycemia, cholesterol and triglycerides serum concentrations were measured in healthy and diabetic rats treated with the aqueous extract of leaves to assess the influence of plant origin (leaves) medicine in the form of tea. These effects have been reported to occur with the use of plants from different regions (Barbosa et al., 2013). Also, the genotoxic effects of these extracts were evaluated using the comet assay in total blood cells obtained from healthy rats that received the extract.

\section{MATERIALS AND METHODS}

\section{Plant and preparation of extracts}

C. icaco leaves were collected in the endemic area of Parque das

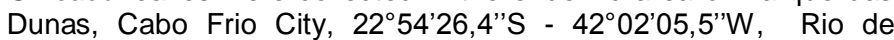
Janeiro State, Brazil, between 9:00 and 10:00 am in spring. To minimize variations induced by environmental factors in plant chemistry, the leaves were processed once to obtain the total extract used during this work. The sample was identified and a voucher was deposited at the Herbarium Bradeanum, at the Rio de Janeiro State University under registration number 85422 .

The leaves from these plants were dried at $37^{\circ} \mathrm{C}$ for six days in B.O.D. (FANEN, SP, Brazil). After this time, the leaves were minced/chopped and boiled in distilled water $(10 \mathrm{~g} / \mathrm{L})$ at $100^{\circ} \mathrm{C}$ for 5 min. This concentration was based on the information gathered among users of Cabo Frio city. Then, tea was filtered, lyophilized and stored at $-20^{\circ} \mathrm{C}$. At the time of use, the extract was dissolved in water at the desired concentration $(0.7 \mathrm{mg} / \mathrm{ml})$ to be given to rats. The same procedure was performed with the dried plant bought from free market.

\section{Treatment of animals}

Adult male Wistar rats, clinical healthy with 220 to $330 \mathrm{~g}$ body weight, were used in this study. They were obtained from the Central Biotery of the Rio de Janeiro State University. The rats were divided into five groups (7/group): group 1 (control), healthy rats; group 2, healthy rats treated with aqueous extract of abajeru from endemic area; group 3, healthy rats treated with aqueous extract of abajeru from the free market; group 4, diabetic rats; group 5, diabetic rats treated with aqueous extract of abajeru from endemic area. Each group contained seven animals. All groups were maintained in appropriate plastic cages with cycle of brightness of $12 \mathrm{~h}$ and controlled temperature $\left(22^{\circ} \mathrm{C}\right)$. Animals could drink daily changed water/extract (from free market or endemic area) ad libitum, for 35 days. Diabetes was induced in rats by injecting intraperitoneally a single dose (45 mg/kg body weight) of streptozotocin (Sigma, St Louis, USA) freshly dissolved in $40 \mathrm{mM}$ citrate buffer ( $\mathrm{pH}$ 4.5) (Hulstijn et al., 2003). Diabetes was confirmed by blood glucose rate above $200 \mathrm{mg} / \mathrm{dl}$, measured 12 days after administration. After confirmation of the hyperglycemia, treatment with the extract was started. The study protocol was approved by the Rio de Janeiro State University ethical committee for animal use.

\section{Biochemistry analysis}

Glucose, triglycerides and cholesterol rates were measured in healthy and diabetic rats after treating with $C$. icaco extracts. The blood glucose was measured at 1st, 15 and 30th days during the 


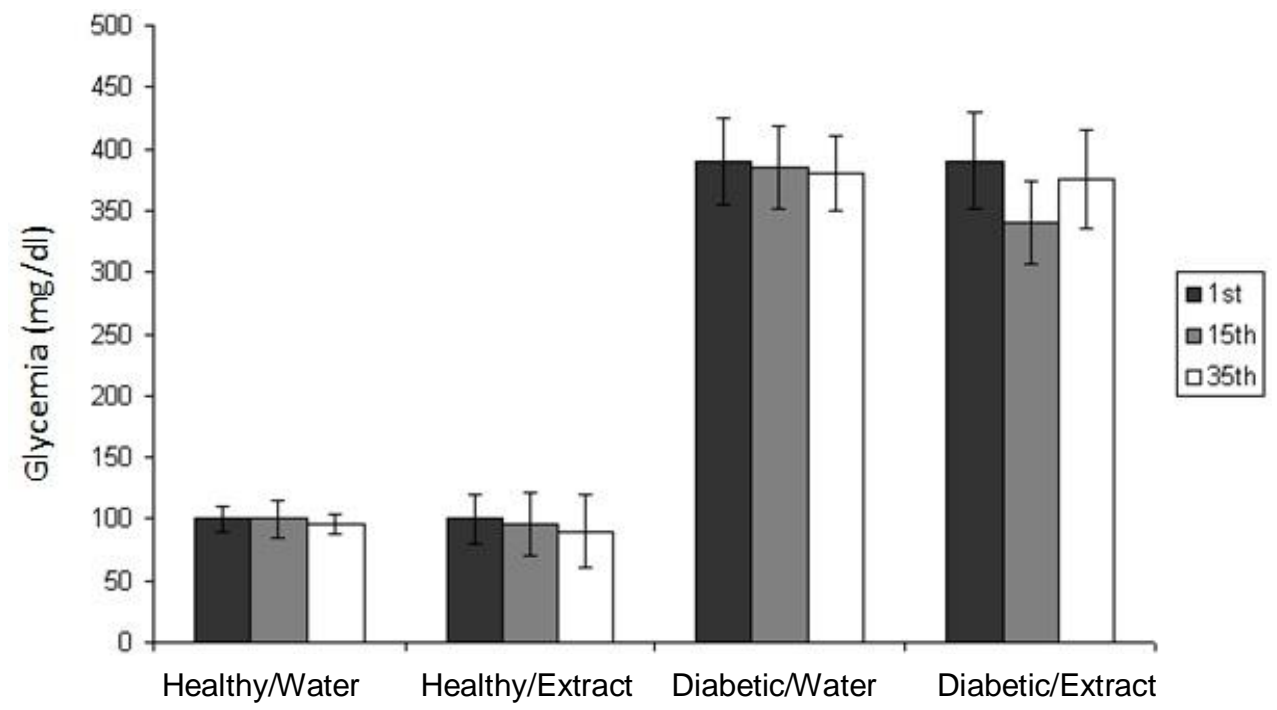

Figure 1. Abajeru aqueous extract (field) effect in glycemia of healthy and diabetic rats. During the treatment total blood samples were collected from each animal in different times (1st, 15th and 35th days) for glycemia analysis. The comparisons between the groups were held by test ANOVA with repeated measures followed by the Student-Newman-Keuls multiple comparison test. Each point represents the mean \pm standard deviation (SD) of seven animals.

treatment; this was done always at 8:00 a.m., before meals; the tails of the rats (groups 1, 4 and 5) were punctured. The glucose concentration was measured using a reflectance apparatus based on glucose-glucose oxidase reaction (Glucometer Elite XL Diabetes Care System - Bayer, Tarrytown, NY).

The concentrations of cholesterol and triglycerides were determined enzymatically with cholesterol oxidase-peroxidase 4aminophenazone (CHOD-PAP) and glycerophosphate oxidaseperoxidase-4-aminophena-zone (GPO-PAP) methods, respectively, on a Cecil CE spectrophotometer (Maitra et al., 1997). For these analyzes samples $(2 \mathrm{ml})$ of total blood from each animal (groups 1 , 4 and 5) treated for 35 days with aqueous extract (endemic area) or just drinking water was obtained by heart puncture.

\section{Single cell gel electrophoresis assay (SCGE)}

Genotoxic potential was studied using the SCGE assay by in vivo assays of an aqueous extract prepared with $C$. icaco $L$. from free market or endemic area on healthy Wistar rats. To detect DNA lesions in healthy rats treated with or not with the extract, a blood sample $(10 \mu \mathrm{l})$ of each animal was removed every 7 days, for 35 days, and mixed to $120 \mu \mathrm{l}$ of low-melting point agarose $(0.5 \%)$. The cell suspension was then placed on microscope slides that were pre-gelatinized with normal melting point agarose $(1.5 \%)$. The slides were then coverslipped and kept refrigerated at $4^{\circ} \mathrm{C}$ to gelify. After $20 \mathrm{~min}$, the slides were immersed in ice-cold alkaline lysing solution $(2.5 \mathrm{M} \mathrm{NaCl}, 10 \mathrm{mM}$ Tris, $100 \mathrm{mM}$ ethylenediaminetetraacetic acid (EDTA), 10\% dimethyl sulfoxide (DMSO), 1\% triton X100 , final $\mathrm{pH}>13$ ) for at least $1 \mathrm{~h}$, protected from light and refrigerated $\left(4^{\circ} \mathrm{C}\right)$. The slides were then placed in an electrophoresis chamber, covered with buffer $(300 \mathrm{mM} \mathrm{NaOH}$ and 1 mM EDTA, pH>13) and maintained in the dark at $4^{\circ} \mathrm{C}$, for $25 \mathrm{~min}$. The electrophoresis was run at $300 \mathrm{~mA}$ and $1.6 \mathrm{~V} / \mathrm{cm}$ for $25 \mathrm{~min}$. The slides were then neutralized with $0.4 \mathrm{M}$ Tris- $\mathrm{HCl}$ buffer, $\mathrm{pH} 7.5$, three times for 5 min each; they were air dried and fixed in absolute ethanol for $10 \mathrm{~min}$. Before being examined, the slides were stained with ethidium bromide $(20 \mu \mathrm{g} / \mathrm{ml})$. DNA of individual cells was analyzed under fluorescence microscopy, with an excitation filter of 516 to $560 \mathrm{~nm}$ from a $50 \mathrm{~W}$ mercury light source and barrier filter, and quantified as described subsequently. For each slide, 100 nuclei were randomly chosen and classified in agreement with the intensity of the tail based on four categories: class 0 (absence of tail); class 1 (tail of up to $1 \times$ the diameter of the nucleus of class 0 ); class 2 (tail of up to $2 \times$ the diameter of class 0 ); class 3 (tail of more than $3 \times$ the diameter of the nucleus of class 0 ). To quantify the lesions produced (arbitrary units), the mean score of the damage was calculated by multiplying the number of cells showing damage in each class ( $n$ ) by the value of the class. Therefore, the final sum of the classes of the 100 comets can vary between 0 (no harmed) and 300 (all harmed to the maximum).

\section{Statistical analysis}

Seven replicates were taken in each treatment to detect the differences between the control and treated groups in the same period of analysis. The data were analyzed by ANOVA with repeated measures followed by the Student-Newman-Keuls multiple comparison test through the statistical program InStat version 3.01 (GraphPad Software, San Diego, CA, USA). Differences were considered significant when $p$ value $<0.05$.

\section{RESULTS}

The results presented in Figures 1 and 2 showed that the abajeru extract from endemic area did not promote modifications in the glucose or cholesterol serum 


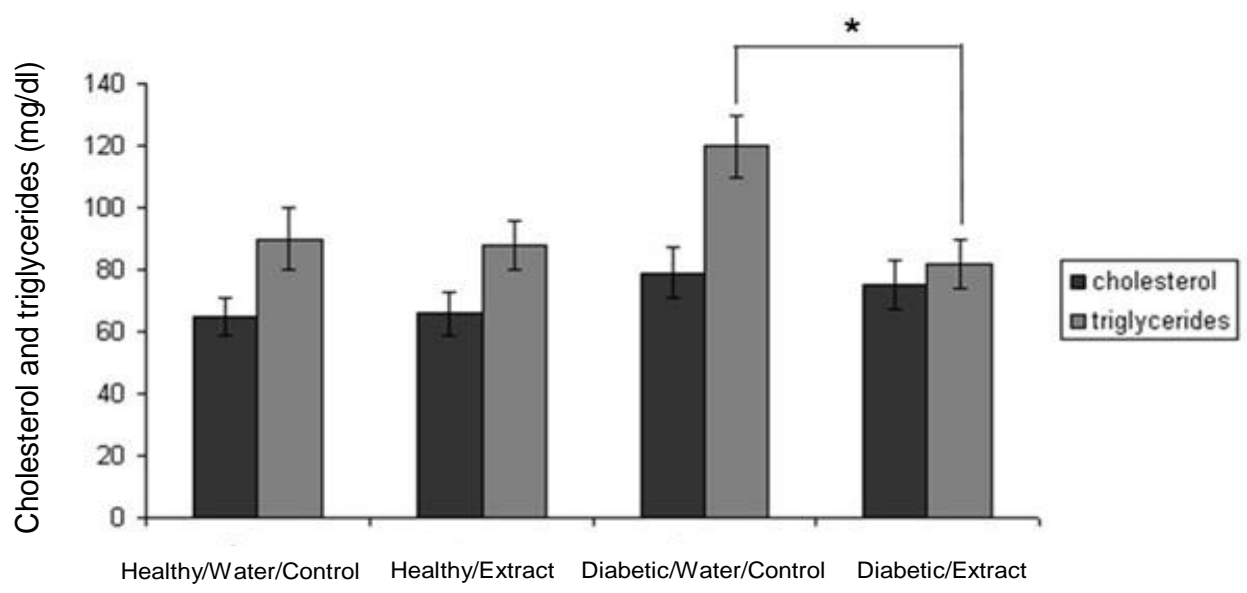

Figure 2. Effect of abajeru aqueous extract (field) in triglycerides and cholesterol levels of healthy and diabetic rats. After the treatment (35th day) blood samples were collected from each animal for analysis. The comparisons between the groups were held by test ANOVA with repeated measures followed by the Student-Newman-Keuls multiple comparison test. Each point represents the mean \pm standard deviation (SD) of seven animals. It was considered significant a difference when $p<0.05$. ${ }^{*}$ Represents significant difference between the control and treated groups in the same period of analysis.

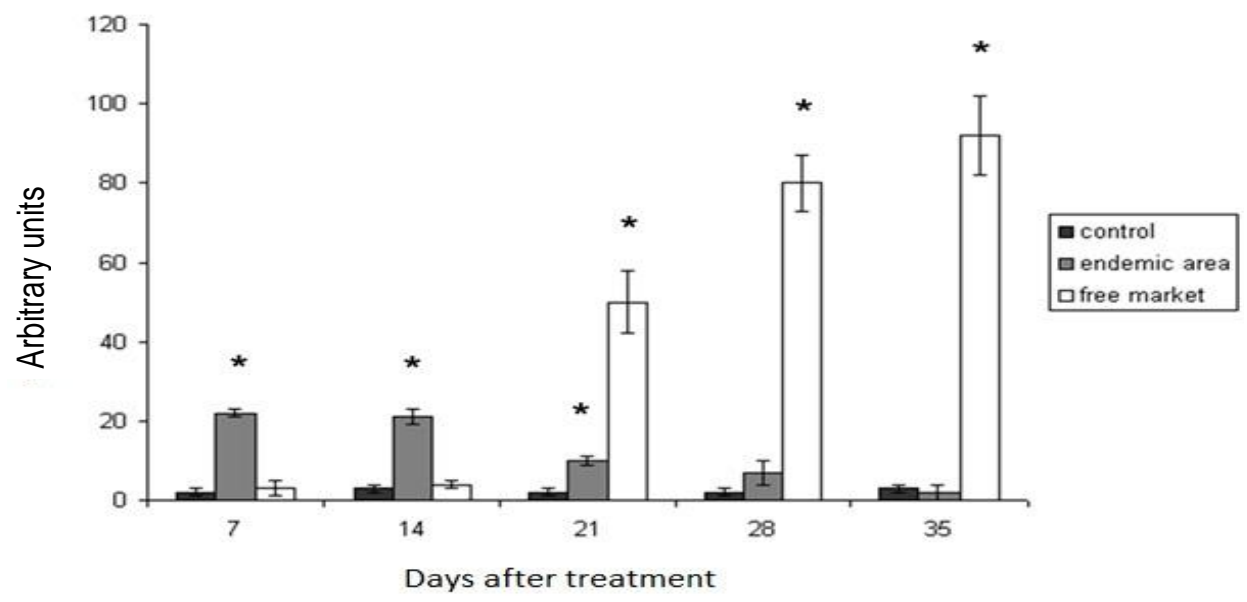

Figure 3. Comet assay of total blood cells from healthy rat groups that received water (control) or aqueous extract of abajeru from free market or field. Every 7 days, a total of 35 days, a sample of blood was drawn from each rat to be assayed in comet assay. The comparisons between the groups were held by test Anova with repeated measures followed by the StudentNewman-Keuls multiple comparison test. Each point represents the mean \pm standard deviation (SD) of seven animals. It was considered significant a difference when $p<0.05$. ${ }^{*}$ Represents significant difference between the control and treated groups in the same period of analysis.

concentrations in diabetic rats. On the other hand, there was a significant decrease $(p<0.05)$ of the triglycerides serum concentration of diabetic treated rats, which was at the same level with the control animals (Figure 2).

The comet assay used to evaluate the genotoxic potential of the abajeru aqueous extract (free market or field) was analyzed based on the presented categories and indicated that the groups that received the extract had a larger amount of lesions in DNA than those that received drinking water (control) (Figure 3).

Regarding the group that received the endemic area aqueous extract, the results indicate that the number of DNA lesions in total blood cells was reduced in the course of time. During the periods of analysis $(7,14$ and 
21 days) after beginning treatment with these extracts, there were significant differences in relation to the control $(p<0.05)$; while at the last time intervals (28 and 35 days), there were no observed differences $(p>0.05)$. On the other hand, the rats treated with the extract from samples of free market presented an opposite profile; the number of lesions became more expressive in elapsing of the treatment, in 21, 28 and 35 days after treatment.

\section{DISCUSSION}

The results presented showed that aqueous extract from field plants did not promote modifications in the glucose or cholesterol serum concentrations in diabetic rats. Other authors observed using a similar experimental model that this extract was unable to inhibit the elevation of postprandial glycemia, in contrast with oral hypoglycemic agent as metformin currently used for the treatment of diabetes (Souza et al., 2009; Barbosa et al., 2013). On the other hand, when chronically administered, it was able to reduce fasting blood glucose of alloxaninduced diabetic mice to similar levels with the metformin (Presta and Pereira, 1987; Barbosa et al., 2013). These different activities in the extracts may be due to the animal model used (rats or mouse), concentrations of the extracts or genotypic differences in plant samples used in these studies. Another hypothesis could be the influence of the environment on the synthesis of special metabolites responsible for the biological effects of the extracts.

The effect of reducing the rate of triglycerides serum concentration in diabetic treated rats, which was at the same level with the control animals, demonstrates the medicinal importance of this species since in diabetic patients high triglycerides serum levels can be a predisposition factor to cardiovascular diseases (AbdelMaksoud et al., 2008; Farmer, 2008).

Regarding genotoxicity, in spite of its crescent use for the treatment or prevention of diseases, great majority of the phytotherapeutic agents continued without scientific background (Maistro et al., 2004; Costa et al., 2008). The medicinal plants in general synthesize toxic substances, which in nature act as a defense against infections, insects and herbivores (Cavalcanti et al., 2006). The results of this work indicated that the extract from free market can present some substances which are absent in the extract from endemic area, favoring their bioaccumulation and consequently explaining the increased lesions number. Most bio-transformations by a detoxication process may involve many oxidative reactions that produce reactive metabolites which can induce genotoxic effects or metabolites that can protect against mutagens (Hodgson and Levi, 1997). Further, chromatography analysis could explain the real differences between the two extracts.

Pharmacological studies showed that leaves from $C$. icaco methanolic extract reduced the formation of new blood vessels (antiangiogenic potential) in chicken chorioallantoic membrane (De Paulo et al., 2000). The same extract contains some triterpenoids able to inhibit growth and induce apoptosis of K562, an erythroleukemia cell line (Fernandes et al., 2003). So, C. icaco extract could represent an important tool against the tumorigenesis process. However, potential genotoxic effects have also been demonstrated, like those observed with normal blood cells in this article. In this way, it is necessary to better understand the conse-quence that the genotoxic products can cause organisms at long-term and whether these substances are linked to the type of extraction performed.

It appears that the beneficial and/or harmful effects of the natural medicinal products typically result from combinations of various components present in the plant (Briskin, 2000; Gilbert and Alves, 2003; Ulrich-Merzenich et al., 2007). Abajeru from Cabo Frio allows better control in the preparation of tea and reproducibility of the experiments. But, the plant from free market lacks information on the origin, conservation and soil where it was grown. Differences as to the origin of plants (genotype, environmental factors), as well as the collection and storage methodologies can affect the composition of the extract, making it dangerous for consumption (Briskin, 2000; Büter et al., 1998; Ksouri et al., 2008). As people have greater access to purchase these herbs in the open market, there exists an urgent need to identify the substances responsible for the therapeutic effect and toxicity so as to enable an orientation of safe use of this plant.

\section{Conclusion}

Aqueous extract of abajeru from Cabo Frio region induced a significant reduction in rates of triglycerides in the blood of diabetic rats, although not devoid of genotoxic effects in blood cells of these mice. However, samples of the same plant species purchased from free markets had significantly higher genotoxic effect, highlighting the danger of indiscriminate use of medicinal plants from uncontrolled sources.

\section{ACKNOWLEDGEMENTS}

This Research was supported by National Council of Scientific and Technological Development-(CNPq), Foundation for the Coordination of Improvement of Higher Education Personnel - (CAPES), Carlos Chagas Filho Foundation for Research Support at State of Rio de 
Janeiro - (FAPERJ) and Coordination General of Environment (Cogema) of Cabo Frio, RJ.

\section{ABBREVIATIONS}

STZ, Streptozotocin; SCGE, single cell gel electrophoresis; CHOD-PAP, cholesterol oxidase-peroxidase 4aminophenazone; GPO-PAP, glycerophosphate oxidaseperoxidase-4-aminophena-zone.

\section{REFERENCES}

Abdel-Maksoud M, Sazonov V, Gutkin SW, Hokanson JE (2008). Effects of modifying triglycerides and triglyceride-rich lipoproteins on cardiovascular outcomes.. doi: 10.1097/FJC.0b013e318165e2e7. J. Cardiovasc. Pharmacol. 51:331-351.

Akinboro A, Bakare AA (2007). Cytotoxic and genotoxic effects of aqueous extracts of five medicinal plants on Allium cepa Linn. doi: 10.1016/j.jep.2007.04.014. J. Ethnopharmacol. 112:470-475.

Barbosa APO, Silveira GO, Menezes IAC, Neto JMR, Bitencurt JLC, Estavam CS, Lima ACB, Thomazzi SM, Guimarães AG, QuintansJunior LJ, Santos MRV (2013). Antidiabetic effect of the Chrysobalanus icaco L. aqueous extract in rats. doi: 10.1089/jmf.2012.0084. J. Med. Food 16:538-543.

Briskin DP (2000). Medicinal plants and phytomedicines linking plant biochemistry and physiology to human health. doi:10.1104/pp.124.2.507. Plant Physiol. 124:507-514.

Büter B, Orlacchio C, Soldati A, Berger K (1998). Significance of genetic and environmental aspects in the field cultivation of Hypericum perforatum. doi: 10.1055/s-2006-957475. Planta Med. 64:431-437.

Cavalcanti BC, Costa-Lotufo LV, Moraes MO, Burbano RR, Silveira ER, Cunha KM, Rao VS, Moura DJ, Rosa RM, Henriques JA, Pessoa C (2006). Genotoxicity evaluation of kaurenoic acid, a bioactive diterpenoid present in Copaiba oil. doi:10.1016/j.fct.2005.08.011. Food Chem. Toxicol. 44:388-392.

Coelho-Ferreira M (2009). Medicinal knowledge and plant utilization in an Amazonian coastal community of Marudá, Pará State (Brazil). J. Ethnopharmacol. 126:159-175.

Collins AR, Oscoz AA, Brunborg G, Gaivão I, Giovannelli L, Kruszewski M, Smith CC, Stetina R (2008). The comet assay: topical issues. Mutagenesis 23:143-151. doi:10.1093/mutage/gem051

Costa RJ, Diniz A, Mantovani MS, Jordão BQ (2008). In vitro study of mutagenic potential of Bidens pilosa Linné and Mikania glomerata Sprengel using the comet and micronucleus assays. doi:10.1016/j.jep.2008.03.014. J. Ethnopharmacol. 118:86-93.

Costa OA (1977). Brazilian plants with hypoglycaemic effects. Leandra 7:63-75.

Dahlgren RMT (1980). A revised system of classification of the angiosperms. doi: 10.1111/j.1095-8339.1980.tb01661.x. Bot. J. Linn. Soc. 80:91-124.

De Paulo S, Balassiano IT, Silva NH, Castilho RO, Kaplan MAC, Cabral MC, Carvalho MGC (2000). Chrysobalanus icaco L. extract for antiangiogenic potential observation. Int. J. Mol. Med. 5: 667-669.

Farmer JA (2008). Diabetic dyslipidemia and atherosclerosis: evidence from clinical trials. doi: 10.1007/s11892-008-0013-2. Curr. Diab. Rep. 8:71-77.

Fernandes J, Castilho RO, Costa MR, Wagner-Souza K, Kaplan MAC, Gattass CR (2003). Pentacyclic triterpenes from Chrysobalanaceae species: cytotoxicity on multidrug resistant and sensitive leukemia cell lines. doi:10.1016/S0304-3835(02)00593-1. Cancer Lett. 190:165-169.

Ferreira-Machado SC, Rodrigues MP, Nunes AP, Dantas FJ, De Mattos JC, Silva CR, Moura EG, Bezerra RJ, Caldeira-de-Araujo A (2004). Genotoxic potentiality of aqueous extract prepared from Chrysobalanus icaco L. leaves. doi:10.1016/j.toxlet.2004.03.014.
Toxicol. Lett. 151:481-487.

Gadano AB, Gurni AA, Carballo MA (2006). Argentine folk medicine: genotoxic effects of Chenopodiaceae family. doi:10.1016/j.jep.2005.08.043. J. Ethnopharmacol. 103:246-251.

Gilbert B, Alves LF (2003). Synergy in plant medicines. Curr. Chem. 10:13-20.

Hodgson E, Levi PE (1997). A Textbook of Modern Toxicology third edition, chapter 14, hepatotoxicity. Appleton \& Lange, Stamford, Connecticut, USA. doi: 10.1002/0471646776.ch14.

Hulstijn M, Barros LA, Neves RH, Moura EG, Machado-Silva JR (2003). Morphological changes in the reproductive organs of male and female Schistosoma mansoni worms caused by streptozotocin, a drug used to induce diabetes mellitus. Parasitology 126:53-61.

Kim BS, Park JJ, Edler L, Von Fournier D, Haase W, Sautter-Bihl ML, Gotzes F, Thielmann HW (2002). New measure of DNA repair in the single-cell gel electrophoresis (comet) assay. doi: 10.1002/em.10090. Environ. Mol. Mutagen. 40:50-56

Ksouri R, Megdiche W, Falleh H, Trabelsi N, Boulaaba M, Smaoui A, Abdelly C (2008). Influence of biological, environmental and technical factors on phenolic content and antioxidant activities of Tunisian halophytes. doi:10.1016/j.crvi.2008.07.024. C R Biol. 331:865-873.

Maistro EL, Carvalho JC, Mantovani MS (2004). Evaluation of the genotoxic potential of the Casearia sylvestris extract on HTC and V79 cells by the comet assay. doi:10.1016/j.tiv.2003.10.002. Toxicol. in vitro 18:337-342.

Maitra A, Hirany V, Jailed, I (1997). Comparison of two assays for measuring LDL cholesterol. Clin. Chem. 43:1040-1047.

Moretti M, Cossignani L, Messina F, Dominici L, Villarini M, Curini M, Marcotullio MC (2013). Antigenotoxic effect, composition and antioxidant activity of Dendrobium speciosum. Food Chem. 140:660665.

Ndiaye M, Diatta W, Sy AN, Dièye AM, Faye B, Bassène E (2008). Antidiabetic properties of aqueous barks extract of Parinari excelsa in alloxan-induced diabetic rats. Fitoterapia 79:267-270.

Ong KC, Khoo HE (2000). Effects of myricetin on glycaemia and glycogen metabolism in diabetic rats. Life Sci. pp. 1695-1705.

Presta GA, Pereira NA (1987). Activity of abageru (Chrysobalanus icaco L., Chrysobalanaceae) in experimental models to the study of hypoglycemiant plants Rev. Bras. Farm. 68:91-101.

Rojas E, Lopez MC, Valverde M (1999). Single cell gel electrophoresis assay: methodology and applications. doi: 10.1016/S03784347(98)00313-2. J. Chromatogr. B. Biomed. Sci. Appl. 722:225-254.

Santos R, Cabral TR, Cabral IR, Antunes LMG, Andrade CP, Cardoso PCS, Bahia MO, Pessoa C, Nascimento JLM, Burbano RR, Takahashi CS (2008). Genotoxic effect of Physalis angulata L. (Solanaceae) extract on human lymphocytes treated in vitro. Biocell 32:195-200.

Souza VH, Barbosa APO, Cardoso GC, Marreto RN, Barreto-Filho JAS, Antoniolli AR, Santos MRV (2009). Evaluation of the antidiabetic potential of five medicinal plants in rats. Lat. Am. J. Pharm. 28:609612.

Tice RR, Agurell E, Anderson D, Burlinson B, Hartmann A, Kobayashi H, Miyamae Y, Rojas E, Ryu JC, Sasaki YF. (2000). Single Cell Gel/Comet Assay: Guidelines for In vitro and In vivo Genetic Toxicology Testing. Environ. Mol. Mutagen. 35:206-221.

Trzeciak AR, Barnes J, Evans MK (2008). A modified alkaline comet assay for measuring DNA repair capacity in human populations. doi: 10.1667/RR1101.1. Radiat. Res. 169:110-121.

Ulrich-Merzenich G, Zeitler H, Jobst D, Panek D, Vetter $\mathrm{H}$, Wagner $\mathrm{H}$ (2007). Application of the "-Omic-" technologies in phytomedicine. doi: 10.1016/j.phymed.2006.11.011. Phytomedicine 14:70-82.

Vargas-Simon G, Arellano-Ostoa G, Garcia-Villanueva E (1997). Propagación por estacas com hojas de icaco (Chrysobalanus icaco) y anatomía del enraizamiento. Proc. Intern. Soc. Trop. Hortic. 41:264-269.

Verschaeve L, Van Staden J (2008). Mutagenic and antimutagenic properties of extracts from South African traditional medicinal plants. doi:10.1016/j.jep.2008.06.007. J. Ethnopharmacol. 119:575-587. 